\title{
PENINGKATAN KETRAMPILAN PRATIKUM MATA KULIAH BAKERY \& PASTRY MAHASISWA TUNA RUNGU MELALUI PENDEKATAN TUTOR SEBAYA DAN MEDIA AUDIO VISUAL
}

\author{
Yunus Karyanto \\ Universitas PGRI Adi Buana Surabaya \\ E-mail:kar_yns@yahoo.co.id
}

\begin{abstract}
Abstrak
Setiap warga negara Indonesia memiliki kesempatan yang sama untuk memperoleh pendidikan. Hal ini juga berlaku kepada anak berkebutuhan khusus atau biasa juga disebut sebagai penyandang disabilitas. Anak berkebutuhan khusus/ penyandang disabilitas juga dapat memperoleh pendidikan setinggi-tingginya. Seperti halnya mahasiswa penyandang disabilitas pada Universitas PGRI Adi Buana Suarabaya, khususnya bagi mahasiswa tuna rungu. Mahasiswa ini diberikan kesempatan yang sama untuk memperoleh pembelajaran seperti mahasiswa lainnyua. Dalam kegiatan pembelajaran yang dilakukan pada mata kuliah Bakery dan Pastry, mahasiswa diberikan pendekatan tutor sebaya dan media audio - visual untuk membantu meningkatkan ketrampilan pratikum dalam mata kuliah Bakery dan Pastry. Pada pendekatan tutor sebaya, mahasiswa diberikan buku ajar yang menjadi panduan untuk saling berdiskusi di kelas. Sedangkan dalam media audio- visual, dibuat berupa media video pembelajaran dengan materi pembuatan brownies kukus. Kedua hal tersebut dilakukan untuk meningkatkan ketrampilan pratikum mahasisiswa dalam mata kuliah Bakery dan Pastry.
\end{abstract}

Kata Kunci : Pratikum, Bakery dan Pastry, Tuna Rungu, Pendekatan Tutor Sebaya, Media Audio Visual

\begin{abstract}
Every Indonesian citizen has the same opportunity to get an education. This also applies to children with special needs or also commonly referred to as persons with disabilities. Children with special needs / people with disabilities can also get the highest education. Like students with disabilities at the PGRI Adi Buana University Surabaya, especially for speech impaired students. These students are given the same opportunity to get learning like other students. In learning activities conducted in the Bakery and Pastry courses, students are given a peer tutoring approach and audio-visual media to help improve the skills of the practice in the Bakery and Pastry courses. In the peer tutoring approach, students are given textbooks that are a guide to discussing in class. Whereas in audiovisual media, it is made in the form of learning video media with material for making steamed brownies. Both of these were carried out to improve student practice skills in Bakery and Pastry courses.
\end{abstract}

Keywords: Practices, Bakery and Pastry, Deaf, Peer Tutor Approach, Audio-Visual Media

\section{PENDAHULUAN}

Pendidikan merupakan sebuah proses pembelajaran bagi setiap orang untuk lebih mengerti, memahami dan berpikir secara kritis untuk mendapatkan kehidupan yang lebih baik. Pendidikan berhak didapatkan oleh semua orang. Dalam UUD pasal 28C ayat 1 menyatakan bahwa "Setiap orang berhak mengembangkan diri melalui pemenuhan kebutuhan dasarnya, berhak mendapat pendidikan dan memperoleh manfaat dari ilmu pengetahuan dan teknologi, seni budaya, demi meningkatkan kualitas hidupnya dan demi kesejahteraan umat manusia". Selain itu, Peraturan Daerah Provinsi Jawa Timur No 3 Tahun 2013 pasal 10 ayat 2 menjelaskan bahwa setiap penyelenggara pendidikan wajib memberikan 
pelayanan khusus bagi peserta didik penyandang disabilitas yang disesuaikan dengan jenis dan kedisabilitasannya.

Penyandang disabilitas atau yang sering disebut sebagai anak berkebutuhan khusus, memiliki hak yang sama untuk mendapatkan pendidikan. Terdapat beberapa kategori umum pada anak berkebutuhan khusus, salah satunya adalah Tuna rungu. Menurut Sardjono dalam Shahira (2017) Tuna rungu adalah mereka yang menderita tuna rungu sejak bayi/lahir, yang karenanya tidak dapat menangkap pembicaraan orang lain, sehingga tak mampu mengembangkan kemampuan bicaranya meskipun tak mengalami gangguan pada alat suaranya.

Penyandang Disabilitas.memiliki kesempatan yang sama untuk memperoleh pendidikan sampai dengan Perguruan Tinggi. Seperti halnya Mahasiswa TunaWicara yang berada pada Universitas PGRI Adi Buana Surabaya pada mata kuliah Bakery dan Pastry. Mahasiswa tunawicara memiliki kegiatan pembelajaran yang sama seperti halnya dengan mahasiswa lainnya, namun disesuaikan dengan kemampuan mahasiswa juga. Mahasiswa tunawicara ini nanti diharapkan dapat memiliki kemampuan yang dapat digunakan untuk berinteraksi dengan masyarakat luar setelah lulus dari Universitas. Dalam mata kuliah bakery dan pastry, mahasiswa tunawicara diberikan pendekatan tutor sebaya dan media audio visual. Kedua hal ini dilakukan untuk dapat meningkatkan ketrampilan pratikum mahasiswa dalam mata kuliah bakery dan pastry. Pendekatan tutor sebaya dilakukan dengan memilih mahasiswa yang memiliki kemampuan yang lebih tinggi dibandingkan dengan mahasiswa yang lain. Pemilihan mahasiswa harus dilakukan dengan tepat supaya materi yang disampaikan dapat sesuai kepada peserta didik. Pendekatan tutor sebaya dipilih untuk menciptakan suasana yang nyaman bagi peserta didik, khususnya bagi mahasiswa tunawicara. Dengan menggunakan pendekatan tutor sebaya, mahasiswa akan lebih leluasa untuk memahami dan bertanya mengenai materi pembelajaran yang dilakukan. Hal ini dikarenakan dalam pendekatan tutor sebaya, yang menjadi penyampai materi adalah mahasiswa yang berada di kelas itu sendiri. Mahasiswa Tunawicara cenderung memiliki kepribadian yang tertutup, sehingga dengan menggunakan pendekatan tutor sebaya diharapkan mahasiswa tunawicara dapat lebih nyaman berinteraksi dalam kegiatan pembelajaran.

Pada mahasiswa tunawicara, komunikasi adalah hal penting yang harus didapat dari lingkungan sekitar. Komunikasi yang tepat dan baik dapat membangun minat dan kemampuan mahasiswa untuk belajar. Dengan adanya saling komunikasi antara mahasiswa normal dan tunawicara, membuat kesempatan penyerapan informasi dalam penyampaian materi pembelajaran lebih besar. Selain menggunakan pendekatan tutor sebaya, pada mata kuliah Bakery dan Pastry juga memilih menggunakan media pembelajaran dalam kegiatan proses pembelajaran.

Media pembelajaran ini dibuat dengan menyesuaikan kemampuan yang dimiliki mahasiswa tunawicara. Media pembelajaran yang dipilih untuk kegiatan proses pembelajaran adalah media audio - visual. Media ini berfungsi untuk menarik minat dan memberikan kemudahan bagi mahasiswa tunawicara untuk menyerap materi pembelajaran. Media audio - visual yang diberikan berupa media video pembelajaran. Pemilihan media video pembelajaran sebagai salah satu alat untuk menyampaiakan materi pembelajaran diharapkan dapat memudahkan mahasiswa lebih mudah memahami materi pembelajaran yang disampaikan.

Penggunaan pendekatan tutor sebaya dan media audio visual dalam kegiatan pembelajaran bagi mahasiswa tunawicara merupakan bagian dari inovasi yang dilakukan dalam proses belajar mengajar. Hal ini dilakukan dengan menyesuaikan keterbatasan mahasiswa tunawicara dalam mempelajari suatu materi. Melalui pendekatan tutor sebaya, mahasiswa tunawicara diajak untuk aktif dalam kegiatan pembelajaran. Memberikan suasana yang nyaman kepada mahasiswa tunawicara untuk belajar dengan mahasiswa lainnya. Sebelumnya, mahasiswa tunawicara hanya diajar oleh dosen langsung. Dengan adanya pendekatan tutor sebaya, mahasiswa akan 
dapat mengurangi rasa kesenjangan pengetahuan yang dimiliki dibandingkan jika harus diajar oleh dosen mata kuliah langsung. Pendekatan tutor sebaya dilakukan setelah pendidik memberikan materi ajar berupa bahan ajar yang telah dibuat untuk mata kuliah bakery dan pastry. Buku ajar ini dibuat untuk memudahkan mahasiswa dalam berinteraksi dan bertukar informasi di dalam kelas. Buku ajar ini menjadi panduan sekaligus pedoman bagi mahasiswa untuk melakukan kegiatan proses pembelajaran.

Selain menggunakan pendekatan tutor sebaya, kegiatan proses pembelajaran bagi mahasiswa tunawicara juga diberikan salah satu media pembelajaran. Media ini berupa video pembelajaran yang berisikan pratikum pembuatan brownies kukus. Media video pembelajaran dibuat untuk memudahkan mahasiswa tunawicara dalam menyerap informasi. Dengan adanya media video pembelajaran, mahasiswa tunawicara akan lebih tertarik dengan materi yang disampaikan.

\section{KAJIAN LITERATUR DAN PENGEMBANGAN HIPOTESIS}

Peraturan Pemerintah Nomor 19 tahun 2005 mengenai Standar Nasional Pendidikan pasal 19 ayat 1 menyatakan bahwa proses pembelajaran pada satuan pendidikan diselenggarakan secara interaktif, inspiratif, menyenangkan menantang, memotivasi peserta didik untuk berpartisipasi aktif, serta memberikan ruang yang cukup bagi prakarsa, kreativitas dan kemandirian sesuai dengan bakat, minat dan perkembangan fisik serta psikologis peserta didik. Oleh karena itu, pelaksanaan pembelajaran dalam suatu lembaga harus diperbaharui secara inovatif, kreatif dan sistematis sesuai dengan potensi daerah setempat namun tetap pada tujuan pembelajaran nasional (Agung S : 2012).

Menurut Kementerian Riset, Teknologi dan Pendidikan Tinggi, terdapat beberapa hal yang harus dilakukan oleh Dosen saat melakuakn kegiatan pembelajaran terhadap mahasiswa tunarungu/tunawicara: (1) Dosen harus memperbanyak bahan atau informasi yang bersifat visual, misalnya gambar, foto, video, tulisan dll. (2) Dosen dianjurkan untuk banyak menggunakan metode demonstrasi, peragaan, praktik langsung. (3) Dosen dianjurkan untuk menggunakan multimedia. Selain itu, mahasiswa penyandang disabilitas Tunarungu/ Tunawicara juga diberikan kesempatan yang sama untuk mengikuti mata kuliah pratikum dalam kegiatan pembelajaran. Berikut adalah panduan untuk melayani mahasiswa disabilitas dalam mata kuliah : (1) Mahasiswa penyandang disabilitas berhak untuk mengikuti mata kuliah pratikum, dan dosen atau perguruan tinggi harus memberi kesempatan yang sama kepada mereka untuk mengikutinya. (2) Dosen atau perguruan tinggi harus mengidentifikasi keberadaan mahasiswa penyandang disabilitas sebagai peserta dan memahami kebutuhan yang harus diakomodasi. Dalam pembuatan kontrak pratikum, dosen sebaiknya menanyakan hal ini kepada mahasiswa yang bersangkutan. (3) Dosen perlu mensosialisasikan kepada mahasiswa lain, atau masyarakat/Lingkungan di tempat pratikum mengenai keberadaan mahasiswa disabilitas dan pentingnya sikap untuk menerima dan menghargai mereka. (4) Tidak menempatkan mahasiswa penyandang disabilitas di komunitas disabilitas, karena hal ini akan mengurangi pengalaman dan tantangan belajar mereka. (5) Tidak menempatkan para mahasiswa penyandang disabilitas dalam satu kelompok yang sama tetapi menyebarkannya secara acak agar mereka memiliki pengalaman berinteraksi dengan mahasiswa lainnya. (6) Tidak mengarahkan mahasiswa penyandang disabilitas untuk melakukan kegiatan praktek yang stereotipikal, misalnya program terapi pijit dalam KKN karena mereka mampu untuk melaksanakan kegiatan akademis sesuai dengan kompetensi keilmuan mereka. (7) Melakukan modifikasi sarana/lingkungan sehingga aksesibel bagi mahasiswa penyandang disabilitas, seperti menyediakan formulir yang aksesibel, lokasi pratikum yang aksesibel dan lain - lain. (8) Perguruan tinggi menyediakan pendamping disabilitas jika diperlukan pratikum (Kementerian, Riset, Teknologi dan Pendidikan Tinggi : 2017 ).

Kegiatan pembelajaran bagi mahasiswa penyandang disabilitas terdapat juga pada Univeritas PGRI Adi Buana Surubaya, khususnya bagi mahasiswa Pendidikan 
Kesejahteraan Keluarga yang memiliki keterbatasan dalam berkomunikasi/ penyandang disabilitas (Tunawicara) . Proses pembelajaran dilakukan pada kegiatan Pratikum Bakery dan Pastry yang diajarkan dari Pendidikan Kesejahteraan Keluarga dalam Mata Kuliah Pendidikan Tata Boga. Pratikum merupakan kegiatan yang dilakukan untuk memecahkan atau membuktikan suatu teori, yang meliputi, mengamati, mengukur sehingga diperoleh data yang kemudian dipergunakan untuk menarik kesimpulan (Lina P : 2012). Kegiatan pembelajaran menggunakan metode pratikum membuat mahasiswa lebih memahami dan dapat ikut langsung merasakan kegiatan pembelajaran secara nyata. Bagi mahasiswa penyandang disabilitas, kegiatan pratikum telah dianjurkan sebagai salah satu pelayanan yang seharusnya dilakukan di setiap Perguruan Tinggi. Tentunya, kegiatan pratikum tersebut dapat disesuaikan dengan kemampuan dan keterbatasan yang dimiliki oleh tiap mahasiswa. Kegiatan pratikum Bakery dan Pastry ini, dimulai dengan melakukan pendekatan tutor Sebaya ( peer teaching) dan kemudian dilanjutkan dengan menggunakan media video audio - visual.

\section{Karakteristik Mahasiswa Tuna rungu}

Tunawicara adalah individu yang mengalami gangguan atau hambatan dalam komunikasi verbal sehingga mengalami kesulitan dalam berkomunikasi. Hal ini dapat disebabkan oleh kurang atau tidak berfungsinya alat- alat bicara, seperti rongga mulut, lidah langit- langit bicara dan pita suara, selain itu kurang atau tidak berfungsinya organ pendengaran yang mengakibatkan keterlambatan perkembangan mahasiswa. Terdapat beberapa faktor yang menyebabkan seseorang disebut Tuna rungu, yaitu : (1) Hereditas atau keturunan, faktor ini terjadi apabila anak tuna rungu dalam kandungan karena diantara keluarga terdapat tunawicara atau membawa gen tunawicara sehingga ketika lahir anak tersebut memiliki gangguan tunawicara. (2) Gangguan Neo natal, faktor ini terjadi karena bayi- bayi prematur yang lahir tidak normal dan lahir dengan organ tubuh yang yang belum sempurna kadang mengakibatkan kebisuan disertai ketulian. (3) Gangguan pos- natal, faktor ini dikarenakan anak sudah dilahirkan menderita infeksi campak yang menyebabkan tuli preseftik, virus akan menyerang cairan koklea, menyebabkan anak menderita otitis media. Akibat yang sama akan terjadi bila anak menderita scaerlet fever, difteri batuk atau tertular sifilis. (4) Infeksi Saluran Pernafasan, faktor ini terjadi karena gangguan pada organ pernafasan serta paruparu, laring atau gangguan pada mulut lidah.

Pada penyandang disabilitas tuna rungu, mahasiswa akan mengalami kurangnya kemampuan untuk berkomunikasi dengan orang lain. Pentingnya komunikasi pada kegiatan pembelajaran mempengaruhi kemampuan mahasiswa untuk menangkap informasi dan pengetahuan yang dilakukan oleh pendidik. Adanya komunikasi yang tepat dapat menimbulkan hal yang baik. Komunikasi yang baik antara peserta didik dan pendidik dapat menimbulkan terciptanya proses belajar mengajar yang tepat. Bahasa yang diberikan oleh pendidik dalam mengajar mempunyai pesan yang sangat penting bahkan jika peserta didik adalah anak berkebutuhan khusus ( Tunawicara). Pentingnya komunikasi yang tepat terhadap mahasiswa tunawicara menentukan keberhasilan dalam proses belajar mengajar. Dalam mengajar mahasiswa tunawicara teknik penyampaian informasi/ pesan harus dilakukan dengan tepat sasaran agar maksud dan tujuan pembicaraan tercapai.

\section{Pendekatan Tutor Sebaya}

Menurut Ningsih dalam Sri (2018) Peserta didik lebih aktif mendalami pengetahuan melalui diskusi dengan tutor sebaya. Melalui pembelajaran dengan menggunakan tutor sebaya, interaksi antar peserta didik dapat terjalin lebih baik. Hal ini dikarenakan, peserta didik tidak memiliki jurang pemisah dalam berkomunikasi dan berdiskusi dalam menyelesaikan setiap permasalahan dibandingkan dengan peserta didik berkomunikasi langsung dengan pendidiknya. Tutor Sebaya dikenal dengan pembelajaran teman sebaya atau antara peserta didik, hal ini bisa terjadi ketika peserta didik yang lebih mampu menyelesaikan pekerjaannya sendiri dan 
kemudian membantu peserta didik yang kurang mampu dalam menyelesaikan pekerjaanya. Tutor sebaya merupakan salah satu strategi pembelajaran untuk membantu memenuhi kebutuhan peserta didik. Hal ini merupakan pendekatan secara kooperatif bukan kompetitif, dalam pendekatan tutor sebaya dapat menimbulkan rasa saling menghargai dan mengerti dibina diantara peserta didik yang bekerja sama ( Maria Ulfah : 2012). Peserta didik yang terlibat tutor sebaya akan merasa bangga atas perannya dan juga belajar dari pengalamannya. Hal ini membantu memperkuat apa yang telah dipelajari dan diperolehnya atas tanggung jawab yang dibebankan kepadanya. Ketika mereka belajar dengan tutor sebaya, peserta didik juga mengembangkan kemampuan yang lebih baik untuk mendengarkan, berkosentrasi, dan memahami apa yang dipelajari dengan cara yang bermakna. Penjelasan melalui tutor sebaya kepada temannya lebih memungkinkan berhasil dibandingkan guru. Peseerta didik melihat masalah dengan cara yang berbeda dibandingkan orang dewasa dan mereka menggunakan bahasa yang lebih akrab ( Yopi Nisa Febianti : 2014 ).

Pendekatan Tutor Sebaya ( peer teaching ) yang dilakukan pada kegiatan pembelajaran Bakery dan Pastry adalah dengan memberikan kesempatan bagi mahasiswa untuk saling berdiskusi dan bertukar pendapat dengan teman lainnya. Pendidikan memberikan buku ajar yang dapat dipelajari oleh mahasiswa dan kemudian digunakan sebagai bahan diskusi dan pembelajaran yang dilakukan oleh mahasiswa. Buku ajar ini berisikan dasar dasar pengetahuan yang harus dimiliki dalam pembelajaran Bakery dan Pastry, seperti : (1) Pengenalan Bahan Dasar Patiseri, (2) Peralatan, pengolahan produk bakery dan pastry , (3) Pengenalan pembuatan Roti , (4) Puff Pastry, (5) Danish Pastry, (6) Cake , (7) Choux Paste. Buku ajar ini dibuat untuk memudahkan mahasiswa dalam memahami materi Bakery dan Pastry. Dengan adanya buku ajar ini, mahasiswa yang sudah diarahkan untuk melakukan pendekatan tutor sebaya akan lebih mudah untuk menjelaskan pengetahuan yang dimiliki kepada mahasiswa lainnya. Selain melakukan kegiatan pembelajaran menggunakan pendekatan tutor sebaya, mahasiswa juga diberikan media audio - visual yang memudahkan mahasiswa untuk lebih memahami pembelajaran dengan lebih baik.

\section{Karakteristik Media Pembelajaran}

Menurut Sihkabuden (2011) Media adalah suatu alat atau sarana atau perangkat yang berfungsi sebagai perantara atau saluran atau jembatan dalam kegiatan komunikasi (penyampaian dan penerimaan pesan) antara komunikator (penyampai pesan) dan komunikan (penerima pesan). Sedangkan istilah pembelajaran adalah upaya untuk membelajarkan siswa. Membelajarkan berarti usaha membuat seseorang belajar. Dalam upaya pembelajaran terjadi komunikasi antara siswa (pebelajar) dengan guru/ pembelajar/ pengajar, sehingga proses pembelajaran seperti ini adalah sebagai bagian proses komunikasi antar manusia. Dari dua artian diatas, media pembelajaran secara singkat dapat dikemukakan sebagai sesuatu (alat, bahan, keadaan) yang dipergunakan sebagai perantara komunikasi dalam kegiatan pembelajaran. Jadi ada tiga konsep yang mendasari batasan media pembelajaran, yaitu: konsep komunikasi, konsep sistem dan konsep pembelajaran.

Harry C. Mc. Kown dalam Sihkabuden (2011) mengemukakan empat fungsi media adalah sebagai berikut : (1) Mengubah titik berat pendidikan formal, yang artinya dengan media pembelajaran yang tadinya abstrak menjadi kongkrit, pembelajaran yang tadinya teoritis menjadi fungsional praktis. (2) Membangkitkan motivasi belajar, dalam hal ini media menjadi motivasi ekstrinsik bagi pebelajar, sebab penggunaan media pembelajaran menjadi lebih menarik dan memusatkan perhatian pebelajar. (3) Memberikan kejelasan, agar pengetahuan dan pengalaman pebelajar dapat lebih jelas dan mudah dimengerti maka media dapat memperjelas hal itu. (4) Memberikan stimulasi belajar, terutama rasa ingin tahu pebelajar selalu dirangsang untuk selalu timbul untuk dipuaskan. 
Dalam membuat media pembelajaran yang sesuai dan dibutuhkan oleh peserta didik, pendidik perlu mempertimbangkan beberaoa faktor dalam memilih media pembelajaran, yaitu: (a) Tujuan pembelajaran. (b) Efektifitas media. (c) Sasaran didik/pebelajar. (d) Ketersediaan media. (e) Biaya pengadaan. (f) Kualitas teknis. Selain itu, terdapat beberapa prinsip umum yang perlu dipertimbangkan pendidik dalam menggunakan media pembelajaran yaitu : (1) Tidak ada media pembelajaran yang dapat menggantikan kedudukan dan peranan pendidik secara utuh. Artinya penggunaan media pembelajaran bukan berarti mengurangi pentingnya pendidik dalam proses belajar mengajar atau mengganti pendidik sepenuhnya di kelas. Media adalah salah satu sumber belajar, si samping sejumlah sumber belajar lainnya. (2) Tidak ada media pembelajaran yang paking baik untuk mencapai semua tujuan pembelajaran. Media hanya cocok untuk tujuam pembelajaran tertentu dan mungkin tidak cocok untuk tujuan pembelajaran yang lain. Artinya setiap jenis media memiliki karakteristik dan kegunaanya masing masing. (3) Media adalah bagian integral dari sistem pembelajaran. Hal ini berarti bahwa media bukanlah sekedar sebagai alat bantu pembelajaran, tetapi merupakan bagian yang tak terpisahkan dari sistem pembelajaran. Dalam proses belajar mengajar, tanpa adanya alat bantu, mungkin kegiatan belajar masih dapat berlangsung, tetapi tanpa media pembelajaran, kegiatan belajar tidak akan terjadi. (4) Media apapun yang hendak digunakan, partisipasi aktif dari pebelajar harus diutamakan. Dengan menggunakan media pembelajaran yang tepat, maka Cara Belajar Siswa Aktif akan tercipta. Aktifitas belajar yang terjadi bukan berpusat pada guru melainkan siswa. (5) Penggunaan media pembelajaran, bukanlah hanya sekedar selingan/ pengisi waktu atau hiburan, melainkan mempunyai tujuan yang menyatu dengan tujuan pelajaran yang telah direncanakan. (6) Pemilihan media pembelajar hendaknya obyektif, tidak berdasarkan kesenangan pribadi. (7) Penggunaan media yang banyak sekaligius justru akan membingungkan siswa. Oleh karena itu, pendidik harus mampu menetapkan media yang paling cocok untuk tujuan pembelajaran yang telah ditetapkan. Pendekatan multi media tidak berarti menggunakan terlalu banyak media sekaligus, tetapi media tertentu dipilih untuk tujuan pembelajaran tertentu dan media lainnya untuk tujuan pembelajaran yang lainnya. (8) Kebaikan dan keburukan media tidak hanya tergantung pada kekongkritan dan keabstarakannya. Media yang kongkrit wujudnya, mungkin sukar dipahami oleh siswa, tetapi sebaliknya media yang nampak abstrak dapat pula memberikan pengertian yang tepat kepada siswa tentang pelajaran. (9) Guru hendaknya kenal betul dengan media pembelajaran yang akan digunakan. Karakteristik setiap media hendaknya dikuasai oleh guru. Disamping itu cara penggunaan masing- masing media sesuai dengan karakteristiknya juga harus benarbenar dikuasai oleh guru. (10) Media apapun yang hendak digunakan, persiapan yang teliti dan matang harus tetap dilakukan (Sihkabuden : 2011).

\section{Media Audio - Visual}

Media pendidikan adalah alat, metode, dan teknik yang digunakan dalam rangka lebih mengefektifkan komunikasi dan interaksi antara guru/dosen dan mahasiswa dalam proses pendidikan dan pengajaran di kelas (Sapto Haryoko : 2009 ). Pendidik diwajibkan untuk menguasai penggunaan media supaya materi pembelajaran yang disampaikan akan sepenuhnya diterima oleh peserta didik. Seiring dengan perkembangan zaman, media pendidikan juga semakin bervariasi atau diartikan dapat mencakup bahan pendidikan yang lebih luas dan mempunyai fungsi pendidikan yang lebih luas juga. Salah satu perkembangan media saat ini adalah dengan menggunakan media audio - visual sebagai salah satu bagian dalam kegiatan pembelajaran. Media audio visual adalah media penyampaian informasi yang memiliki karakteristik audio (suara) dan visual (gambar). Jenis media ini mempunyai kemampuan yang lebih baik, karena meliputi kedua karakteristik tersebut. Media audio visual dapat dibagi menjadi dua, yaitu: (1) Audio - visual diam, yaitu media yang menampilkan suara dan gambar diam seperti film bingkai suara (sound slide), film bingkai 
suara dan cetak suara. (2) audio - visual gerak, yaitu media yang dapat menampilkan unsur suara dan gambar yang bergerak seperti film suara dan video cassete. Efektivitas pembelajaran melalui media visual dapat terlihat dari tingkat kenikmatan siswa/mahasiswa ketika belajar (membaca) teks yang bergambar atau moving. Menrut Azhar dalam Sapto (2009) mengemukakan bahwa pemakaian media pembelajaran dalam proses pembelajaran dapat membangkitkan keinginan dan minat yang baru, membangkitkan motivasi dan rangsangan kegiatan belajar, dan membawa pengaruh pengaruh psikologis terhadap siswa.

Penggunaan media pembelajaran akan sangat membantu keefektifan proses pembelajaran dan penyampaian isi pelajaran, sesuai dengan tuntutan kurikulum. Efektivitas pembelajaran secara konseptual dapat diartikan sebagai perlakuan dalam proses pembelajaran yang memiliki ciri- ciri : (1) Suasana yang dapat berpengaruh atau hal yang berkesan terhadap penampilan dan (2) keberhasilan usaha atau tindakan yang berpengaruh terhadap hasil belajar peserta didik. Efektivitas pembelajaran melalui media visual dapat terlihat dari tingkat kenikmatan mahasiswa ketika belajar (membaca) teks yang bergambar atau moving. Gambar, simbol atau lambang visual dapat menggugah emosi dan sikap siswa. Dalam kaitannya dengan hasil pembelajaran, setiap kegiatan yang berlangsung pada akhirnya akan dituntut hasil akhir dari kegiatan tersebut, demikian pula dalam pembelajaran untuk mengetahui berhasil tidaknya seseorang yang belajar, maka seseorang akan dapat diketahui tingkat penguasaan tentang materi pelajaran yang telah dipelajari. Hasil dari pembelajaran itu disebut hasil belajar. Jadi hasil belajar adalah hasil yang dicapai oleh siswa setelah melakukan kegiatan belajar dimana hasil tersebut merupakan gambaran penguasaan pengetahuan dan ketrampilan dari peserta didik yang berwujud angka dan tes standar yang digunakan sebagai pengukur keberhasilan. Angka atau skor sebagai hasil pengukuran mempunyai makna jika dibandingkan dengann patokan sebagai batas yang menyatakan bahwa peserta didik telah menguasai secara tuntas materi pelajaran tersebut (Sapto Haryoko : 2009).

Dengan menggunakan media audio - visual dapat memperlancar pemahaman dan memperkuat ingatan, sehingga pada akhirnya diharapkan mahasiswa dapat mengoptimalkan kemampuannya dan potensinya. Media audio- visual yang disampaiakn kepada mahasiswa tunawicara pada kegiatan pembelajaran adalah berupa video. Dalam video ini, berisi mengenai praktik pembuatan/ pemngolahan salah satu contoh dari bakery dan pastry yaitu : Brownies. Pembuatan video pembelajaran pembuatan brownies kepada mahasiswa tuna rungu berguna untuk memudahkan mahahsiswa memahami pengetahuan yang diberikan. Dengan adanya media video pembelajaran ini, mahasiswa akan dapat mengetahui gambaran dalam pembuatan brownies kukus secara rinci dan tepat. Pemberian video pembelajaran ini digunakan utuk menambah wawasan bagi mahasiswa dan digunakan untuk meningkatkan ketrampilan dalam kegiatan pratikum mata kuliah bakery dan pastry.

\section{METODE PENELITIAN}

Penelitian dilakukan untuk dapat memahami dan memecahkan masalah yang ada dalam lingkungan tersebut ( Sugiyono: 2015). Dengan melakukan penelitian, maka permasalahan yang ada dapat diatasi dengan cara yang tepat dan sesuai. Penelitian memerlukan metode yang sesuai untuk mendapatkan data dan informasi yang tepat. Beberapa jenis-jenis metode penelitian dipilih secara tepat sesuai dengan tujuan dan tingkat kealamiahan tempat penelitian. Dalam penelitian ini, jenis penelitian yang digunakan adalah dengan menggunakan metode penelitian kulitatif deskriptif.

Metode penelitian kualitatif adalah metode penelitian yang digunakan untuk meneliti kondisi obyek secara nyata dan apa adanya, dimana kedudukan peneliti sebagai instrumen kunci (Sugiyono : 2015).

Teknik pengumpalan data yang dilakukan pada penelitian ini adalah dengan menggunakan wawancara, observasi dan 
dokumentasi. Setelah data terkumpul, hasil data kemudian diolah dengan menggunakan analisis deskriptif.

\section{HASIL DAN PEMBAHASAN}

\section{Pengaruh Pendekatan Tutor Sebaya dan Media Audio Visual terhadap Mahasiswa Tuna rungu pada Mata Kuliah Bakery dan Pastry}

Kegiatan proses pembelajaran pada mata kuliah Bakery dan Pastry sebelumnya hanya menggunakan metode konvensional. Dengan adanya mahasiswa tunawicara dalam kelas, maka diperlukan beberapa inovasi untuk mengembangkan kegiatan pembelajaran. Inovasi yang dilakukan dalam kegiatan pembelajaran adalah dengan melakukan pendekatan tutor sebaya dan memberikan media audio - visual bagi mahasiswa tunawicara. Kedua hal tersebut dipilih dengan menyesuaikan kemampuan yang dimiliki mahasiswa tersebut. Berikut adalah gambaran kegiatan yang dilakuakan dalam proses pembelajaran :

\section{Perencanaan}

Rencana inovasi pada pembelajaran mata kuliah bakery dan pastry yaitu pada strategi pembelajaran. Strategi dalam pembelajaran mata kuliah bakery dan pastry adalah pembelajaran kongkrit dan Tutor sebaya berperan memberikan bantuan kepada mahasiswa berkebutuhan khusus, khususnya pada mahasiswa tunawicara dalam mensimulasikan proses pemahaman teori atau pratikum . Pembelajaran kongkrit yang digunakan dalam proses pembelajaran adalah dengan memberikan media pembelajaran berupa media audio - visual (video pembelajaran). Pendekatan tutor sebaya dilakukan dengan memilih mahasiswa yang memiliki kemampuan pengetahuan yang lebih tinggi daripada mahasiswa lainnya untuk menyampaikan materi yang telah dipahami. Materi pembelajaran bakery dan pastry telah diberikan oleh pendidik melalui buku ajara yang berisikan dasar- dasar pengetahuan bakery dan pastry. Melalui buku ajar ini, mahasiswa dapat berdiskusi dengan mahasiswa lainnya dengan lebih mudah. Hal ini dikarenakan buku ajar menjadi panduan atau pedoman dalam kegiatan pembelajaran. Mahasiswa tunawicara diberikan kesempatan lebih luas untuk berinteraksi dengan mahasiswa lainnya melalui kegiatan ini. Karena salah satu kunci keberhasilan untuk memahami materi pembelajaran adalah dengan komunikasi yang baik. Dengan melakukan komunikasi yang baik terhadap mahasiswa lainnya, mahasiswa tunawicara akan lebih mudah untuk menyerap materi pembelajaran. Kemudian penggunaan media pembelajaran berupa video pembelajaran dilakukan untuk menambah wawasan dan pengetahuan mahasiswa tunawicara. Media pembelajaran ini disesuaikan dengan kemampuan yang dimiliki mahasiswa tunawicara (audio -visual).

Indikator keberhasilan pelaksanaan perkuliahan dengan model inovasi ini yaitu mahasiswa mampu memahami teori dan pengkajian serta mampu mempraktekan pembuatan kue-kue yang termasuk dalam jenis bakery dan pastry. Dalam proses perencanaan kegiatan perkuliahan maupun pratikum, dosen pengampu mata kuliah bekerjasama dengan beberapa stakeholder diantaranya industry bakery dan pastry, baik dalam slaka industry kecil maupun besar. Stakeholder berperan menjadi penyedia tempat sebagai sarana praktik di lapangan secara langsung oleh mahasiswa. Stakeholder juga bersedia mambagikan ilmu pengetahuan kepada mahasiswa terkait prosedur pelaksanaan produksi pembuatan bakery dan pastry yang digunakannya.

\section{Pelaksanaan}

Pelaksanaan inovasi pembelajaran kongkrit oleh dosen berbasis visual dengan metode tutor teman sebaya pada mata kuliah bakery dan pastry berjalan tanpa kendala yang berarti. Pada proses pelaksanaan inovasi dalam bentuk tutor sebaya, dosen harus berperan aktif membantu menunjuk mahasiswa yang telah menguasai materi dengan baik. Hal ini bertujuan agar proses transfer knowledge antar mahasiswa dapat berjalan dengan baik. Dampak diterapkannya inovasi dengan metode pembelajaran kongkrit oleh dosen berbasis visual dan tutor sebaya adalah meningkatkan pemahaman 
mahasiswa berkebutuhan khusus semakin baik. Mahasiswa berkebutuhan khusus pada mata kuliah ini mengalami ketunawicaraan / tuna rungu yang memiliki karakteristik kepribadian tertutup, sehingga dengan metode pembelajaran kongkrit oleh dosen berbasis visual dan tutor sebaya dapat membantu mereka untuk semakin terbuka dalam berbagi pengetahuan dengan teman .

\section{Evaluasi}

Indikator katercapaian inovasi pada mata kuliah bakery dan pastry adalah mahasiswa menguasai konsep, teori, dan prinsip-prinsip,dalam bakery and pastry, bahan dasar dan peralatan yang digunakan pembuatan bakery and pastry, membedakan jenis-jenis bakery and pastry, display and show piesces, pembuatan perencanaan bakery dan pastry, serta mampu mempraktekkan pembuatan jenis kue yang termasuk bakery and pastry secara umum dan pembelajaran.

\section{KESIMPULAN DAN SARAN}

Pendidikan wajib dimiliki oleh semua orang, seperti yang telah diatur dan sesuai dengan Standar Pendidikan Nasional. Semua masyarakat Indonesia memiliki kesempatan yang sama untuk dapatmemperoleh pendidikan. Hal ini juga termasuk pendidikan yang dapat dimiliki oleh anak berkebutuhan khusus atau juga bisa disebut sebagai penyandang disabilitas. Pendidikan bagi penyandang disabiitas juga telah diatur dan disetujui dilakukan di Indonesia. Pendidikan dapat dimiliki penyandang disabilitas sampai mereka Perguruan Tinggi sesuai dengan kebijakan Kementerian Riset, Teknologi dan Pendidikan Perguruan Tinggi. Mahasiswa penyandang disabilitas di Universitas PGRI Adi Buana Surabaya, khususnya bagi mahasiswa tunawicara diberikan pendekatan tutor sebaya (peer teaching) dan media audio - visual untuk meningkatkan ketrampilan dalam kegiatan pratikum Mata Kuliah Bakery dan Pastry. Dalam pendekatan tutor sebaya, diberikan bahan ajar berupa buku ajar yang berisi pengetahuan dasar mengenai Bakery dan Pastry. Sedangkan dalam media audio - visual, dibuat berupa video pembelajaran yang berisikan pembuatan brownies kukus. Kedua hal tersebut, dilakukan untuk meningkatkan ketrampilan mahasiswa tunawicara dalam mata kuliah Bakery dan Pastry. Pada media audio - visual mahasiswa tunawicara dapat menangkap dan menyerap informasi dan materi pembelajaran dengan baik. Hal ini dapat dikatakan bahwa pemggunaan media pembelajaran berupa video pembelajaran dapat menjadi hal positif bagi kegiatan pembelajaran mahasiswa tunawicara

\section{REFERENSI}

Awaluddin, A. 2016. Komunikasi Nonverbal Antara guru dan Sisswa Tunawicara SLBN Sombu Opu Kabupaten Gowa (Doctoral Dissertation, Universitas Islam Negeri Alauddin Makassar)

Besar,S.L.B.N.S., Darmayanti,D.N. Tantri,A.A.S., \& Sentaya,I.M. 2015. Media Pembelajaran Berbasis Multimedia untuk penyandang Disabilitas Khusus Tunawicara (Kelas 1 Semester 1 Mata Pelajaran Bahasa Indonesia. Jurnal Kependidikan,14(1), 2936)

Dirgantara,D. 2010. Penerapan Pendekatan tutor Sebaya untuk Mengurangi Kesalahan Siswa dalam Menyelesaikan Soal - soal Cerita Kubus dan Balok pada Siswa SMP Negeri 2 Tanggul Kelas VIII semester Genap Tahun Pelajaran 2009/2010

Febianti,Y.N. 2014. Peer Teaching (Tutor Sebaya) Sebagai Metode Pembelajaran Untuk Melatih Siswa Mengajar. Edunomic Jurnal Pendidikan Ekonomi,2(2)

Fitria,N. 2015. Pemenuhan Hak Aksesbilitas Sebagai Wujud Kesamaan Kesempatan Bagi Mahasiswa Penyandang Cacat Dalam Proses Pendidikan (Studi Di Universitas Brawijaya Malang) (Doctoral 
WAHANA

Volume 70, Nomor 2, 1 Desember 2018

dissertation,University

of

Muhammadiyah Malang)

Hayati,Z. 2013. Pengaruh Metode Diskusi Kelompok Tutor Sebaya Terhadap Aktivitas dan Hasil Belajar Mata Pelajaran Biologi di SMA Srijaya Negara Palembang. Palembang: Universitas Sriwijaya

Haryoko,S. 2009. Efektivitas pemanfaatan media audio-visual sebagai alternatif optimalisasi model pembelajaran. Jurnal Edukasi Elektro, 5(1)

Kementerian Riset, Teknologi dan Pendidikan Tinggi.2017. Panduan Layanan Mahasiswa Disabilitas di Perguruan Tinggi.Direktorat Jenderal Pembelajaran dan Kemahasiswaan

Lina, P. 2012. Efektivitas Metode Praktikum dengan Alat Peraga Periskop Sederhana Pelajaran IPA terhadap Kreativitas Siswa Kelas V SD Kanisius Cungkup Kecamatan Sidorejo Kota Salatiga Semester
II Tahun Pelajaran 2011/2012 (Doctoral dissertation, Program Studi Pendidikan Guru Sekolah Dasar FKIP-UKSW).

Olivia,S. 2015. Deteksi Dini Psikologi. Elex Media Komputindo

Peraturan Daerah Provinsi Jawa Timur No 3 Tahun 2013 pasal 10 ayat 2

Peraturan Pemerintah Nomor 19 tahun 2005 mengenai Standar Nasional Pendidikan pasal 19 ayat 1

Setiawan, A. 2012. Metode Pratikum dalam Pembelajaran Pengantar Fisika SMA: Studi Pada Konsep Besaran dan Satuan Tahun Ajaran 2012 2013

Ulfah,M.2012. Optimalisasi Hasil Belajar IPA tentang Sistem Gerak pada Manusia melalui Metode Diskusi dengan Tekhnik Pembelajaran Tutor Sebaya. Jurnal Pendidikan Tindakan Kelas ,3(1)

UUD pasal $28 \mathrm{C}$ ayat 1 